\title{
Sr-rich apatite from the Dangzishan leucitite-ijolite xenoliths (Heilongjiang Province): Mineralogy and mantle-fluid metasomatism
}

\author{
ZHANG WenLan $^{1 *}$, SHAO JiAn ${ }^{2}$, WANG RuCheng ${ }^{1}$, XU XiSheng $^{1}$, CHE XuDong $^{1}$ \& \\ YANG YueHeng ${ }^{3}$ \\ ${ }^{1}$ State Key Laboratory for Mineral Deposits Research, School of Earth Sciences and Engineering, Nanjing University, Nanjing 210093, China; \\ ${ }^{2}$ School of Earth and Space Sciences, Peking University, Beijing 100871, China; \\ ${ }^{3}$ State Key Laboratory of Lithospheric Evolution, Institute of Geology and Geophysics, Chinese Academy of Sciences, Beijing 100029, China
}

Received April 28, 2010; accepted August 19, 2010

\begin{abstract}
Abundant apatite grains with elevated SrO content were found in leucitite-ijolite xenoliths in the Dangzi Mountain, Heilongjiang Province. Morphological and mineralogical associations, and compositional analysis of the Sr-rich apatite, were carried out using an electron microprobe. Two principal types of apatite were distinguished. One type occurs as short-prismatic crystals with Sr-rich rims, while another type with acicular or finely columnar shapes constitutes Sr-rich apatite element maps and systematic quantitative analysis of apatite revealed great variations in $\mathrm{SrO}$ content $(0.42 \%-26.79 \%)$. The calculated structural formula of the measured Sr-rich apatite is: $\left(\mathrm{Ca}_{3.15-4.963} \mathrm{Sr}_{0.019-1.510} \mathrm{Ba}_{0.00-0.030} \mathrm{Na}_{0.006-0.108} \mathrm{REE}_{0.106-0.153}\right)\left(\mathrm{P}_{2.84-3.028} \mathrm{Si}_{0.009-0.094}\right) \mathrm{O}_{12}\left(\mathrm{~F}_{0.675-1.079}, \mathrm{Cl}_{0.000-0.256}\right.$, $\mathrm{OH}_{0.084-0.297}$ ). Mineralogical textures of apatite implied a replacement mechanism for the Sr-rich apatite. Sr-rich rims of apatite are suggested to have formed after metasomatism (isomorphic replacement) of early fluorapatite in a Sr-, light rare-earth elements (LREE), lithophile light elements (LILE)- and volatile-rich residual melt during late magmatism. However, the acicular apatite probably directly crystallized from a Sr-rich residual melt.The $\mathrm{Sr}-\mathrm{Nd}$ isotopic composition of the apatite was distinctive from that of leucitite-ijolite and its host rock. These differences, combined with mineralogical features of apatite, imply that Sr-LREE-LILE-volatile-rich components in the residual melt were derived from deep in the asthenosphere, and subsequently were enriched at a late stage in magma evolution.
\end{abstract}

leucitite-ijolite xenolith, Sr-rich apatite, isomorphic replacement, depleted-mantle fluids, Dangzi Mountain, Heilongjiang Province

Citation: Zhang W L, Shao J A, Wang R C, et al. Sr-rich apatite from the Dangzishan leucitite-ijolite xenoliths (Heilongiang Province): Mineralogy and mantlefluid metasomatism. Chinese Sci Bull, 2011, 56: 53-63, doi: 10.1007/s11434-010-4228-7

Strontium is an important substituting element in natural apatite. Sr-rich apatite is widely found in alkaline rocks, kimberlites, pegmatites and lamprophyre. Studies of Sr-rich apatite have mainly focused on its mechanism of genesis in different geological settings; its crystal-structural modification as a result of $\mathrm{Sr}$ substitution in the Ca site; sources of Sr-rich fluids; and influence of Sr-rich fluid evolution on melt basicity [1-6]. In China, while there are many large

*Corresponding author (email: zhangwl@nju.edu.cn) alkaline complexes (e.g. Baiyun Obo [7]) and pegmatites (e.g. Altay), Sr-rich apatite has not been reported extensively. Wang et al. mentioned the presence of Sr-rich apatite only in the world-famous Koktokay pegmatites in Altai [8]. Sr-rich apatite was reported recently from the Kunyang rift zone, in mantle-source carbonates, and co-existing nephelite, basanite and alkali basalts [9]. Accurate $\mathrm{SrO}$ contents have been published only for Sr-rich phos- phate glass [10,11].

A number of K-rich ultrabasic xenoliths, which have 
been classified as leucitite-ijolite based on mineral composition and content [12,13], have been reported in Keluo volcanic rocks, Heilongjiang Province, particularly in the Dangzishan area. Our previous petrographic investigations showed evidence of extensive metasomatic features in leucitite-ijolite xenoliths. Metasomatism gives rise to the formation of Sr-, Ba-, light rare-earth elements (LREE)-, lithophile light elements- and volatile-bearing minerals, among which is Sr-rich apatite. In this paper, we describe the occurrence, morphology, and chemical composition of Sr-rich apatite in these leucitite-ijolite xenoliths through an electron-microprobe study. Laser ablation inductively coupled plasma mass spectroscopy (LA-ICP-MS) $\mathrm{Rb}-\mathrm{Sr}$ and Sm-Nd analyses also were carried out on the apatites to obtain a better understanding of the source of the Sr-rich fluids.

\section{Geological setting}

Dangzishan volcanic rocks are subordinated to the northernmost Cenozoic K-rich ultrabasic volcanic region of Keluo, located in Nenjiang, Heilongjiang Province, China. Keluo volcanoes formed in a NNW-strike potassic volcanic belt aligned with the southern Wudalianchi and Erkeshan volcanoes. The Dangzi Mountain is situated in the southwestern por- tion of the Keluo volcanic region (Figure 1). The main body of the volcanic zone is characterized by K-rich ultrabasic extrusive rocks, which contain widespread leucitite-ijolite xenoliths (approximately $5 \%$ of the host rock [12]). The xenoliths $(20-40 \mathrm{~cm}$ in diameter) are scattered throughout the ultrabasic rocks as irregular rounded shapes.
Two xenolith samples used in this study were obtained at the top of the Dangzi Mountain (E125 $\left.40^{\prime} 02^{\prime \prime}, \mathrm{N} 49^{\circ} 14^{\prime} 15^{\prime \prime}\right)$. According to a previous whole-rock K-Ar dating study, the age of the Dangzishan volcanic rocks is $2.98 \mathrm{Ma}$ [14]. However, our recent Ar-Ar dating study of nephelite from the xenoliths and leucite from the host rock shows their ages as $13.5 \pm 0.4$ Ma and 12.8 $\pm 0.5 \mathrm{Ma}$, respectively [15].

\section{Samples and analytical methods}

Two xenolith samples were used in this study. One oval-shaped xenolith (K-DZS-05, $40 \mathrm{~cm} \times 30 \mathrm{~cm}$ ) was surrounded by the host rock (Figure 2(a)). The boundary between the xenolith and the host rock was quite distinct. The other xenolith had an irregular shape and was separated from the host rock by weathering (K-DZS-06, $20 \mathrm{~cm} \times 30$ $\mathrm{cm}$ ) (Figure 2(b)). Both samples were mainly grey, coarsegrained and porous Euhedral to sub-euhedral augites were observed with the naked-eye, were approximately 5-10 mm long, and comprised more than $35 \%$ of the sample. The other light-colored minerals were generally euhedral.

Polished thin sections were prepared for electron microprobe (EMP) analyses at the State Key Laboratory for Mineral Deposits Research, Nanjing University (JEOL JXA8100 microprobe). The analyses were performed at $15 \mathrm{kV}$ accelerating voltage and $20 \mathrm{nA}$ beam current. The analyzing crystals were PET ( $\mathrm{Sr}, \mathrm{Ca}, \mathrm{P}, \mathrm{K}$ and $\mathrm{Cl}$ ), LiF (Fe, Mn, La, $\mathrm{Ce}, \mathrm{Sm}, \mathrm{Nd}$ and Pr), LED1 (F) and TAP (Na, Si and Mg). The measurement of $\mathrm{Ba}$ using the PET crystal is easily disturbed by the Ti peak; therefore, measurement of $\mathrm{Ba}$ was performed using the $\mathrm{LiF}$ crystal. Counting times to determine

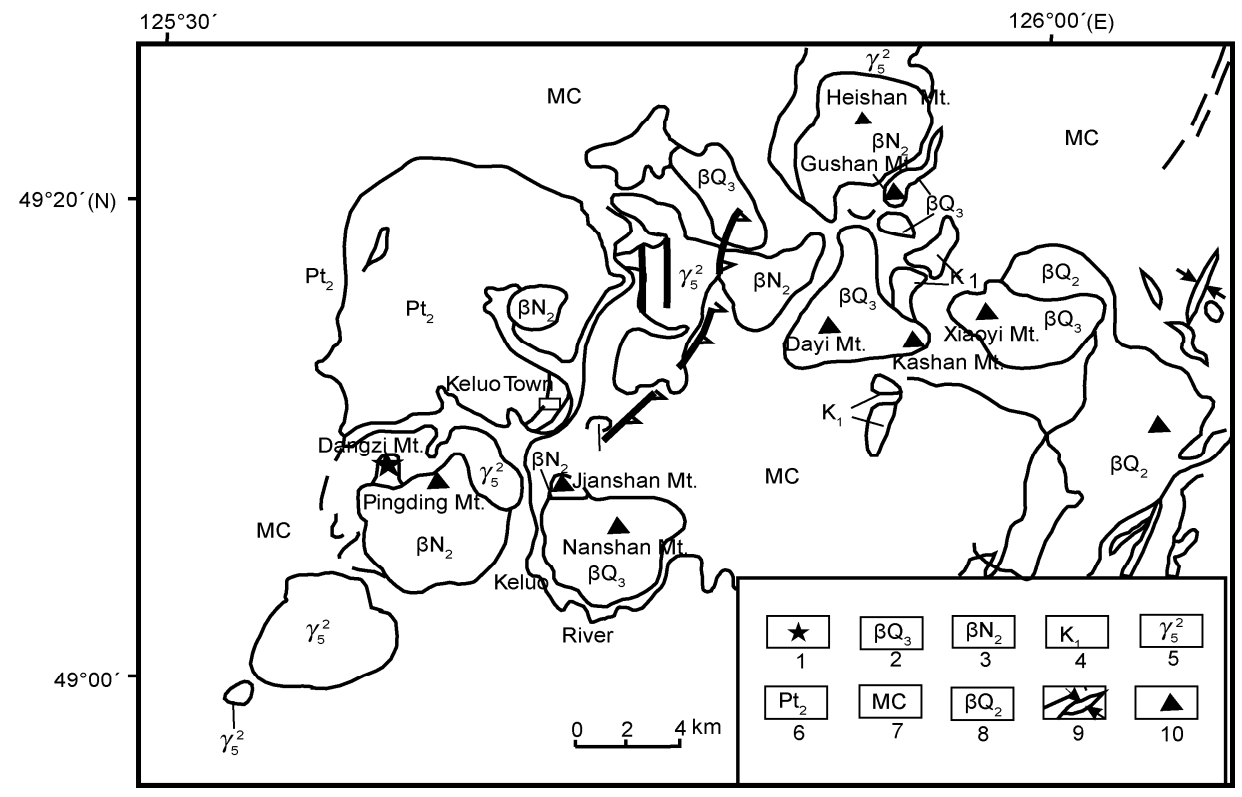

Figure 1 Geological map of the Keluo volcanics (after Mu, 1992 [14]). 1. Sample site of this study; 2, Late Quaternary basalt; 3, Late Tertiary basalt; 4, Cretaceous basalt; 5, Yanshanian granite; 6, Precambrian granite; 7, Mesozoic and Cenozoic sedimentary rocks; 8, Early Quaternary basalt; 9, fault; 10, volcanic cone. 

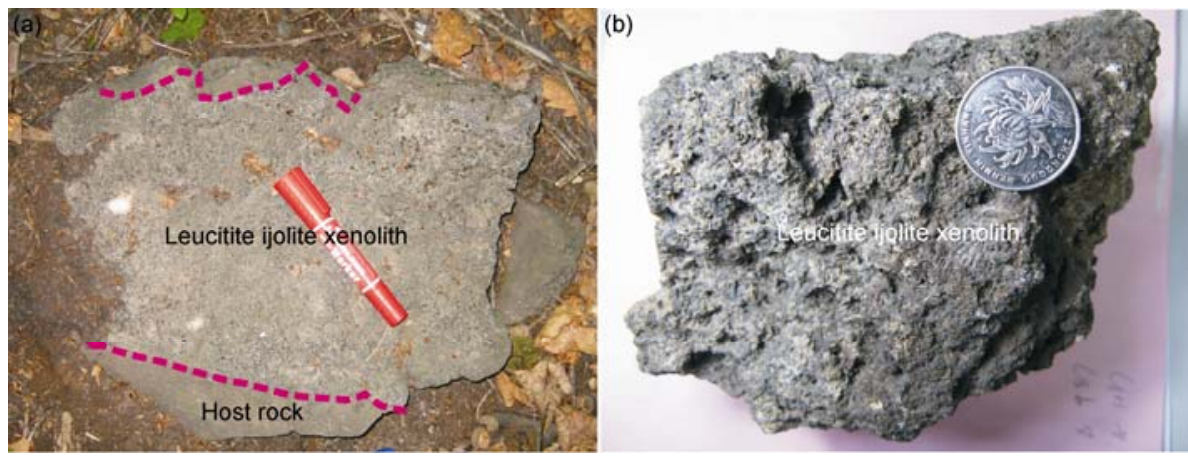

Figure 2 Xenolith samples used in this study.

the peak positions of LREE, Sr, Ba, Mn, Fe, Si and $\mathrm{Mg}$, versus the background were $20 \mathrm{~s}$ and $10 \mathrm{~s}$. Counting times to determine peak positions of $\mathrm{Na}$ and $\mathrm{K}$ versus background were $10 \mathrm{~s}$ and $5 \mathrm{~s}$. All standards used in the analyses were from the American National Standards Institute (ANSI). Because of the volatility of $\mathrm{Na}, \mathrm{F}$ and $\mathrm{Cl}$ in the EMP analysis, the beam spot diameter was set at $2 \mu \mathrm{m}$, and these three elements were analyzed first during every run of the spectrometer to minimize the numbering reduction caused by volatilization.

$\mathrm{Sr}-\mathrm{Nd}$ isotopic analyses of the Sr-rich apatites were performed in the Plasma Mass-Spectrometer Laboratory at the Institute of Geology and Geophysics, Chinese Academy of Science. The instrument was a Neptune multi collector (MC)-ICP-MS installed with a $193 \mathrm{~nm}$ laser. The sampleleucitite-ijolite inclusion, containing Sr-rich apatites, was pulverized into 60 meshes first, and then the possible Sr-rich apatite crystals were selected under a binocular microscope. A similar procedure was used in sampling for $\mathrm{U}-\mathrm{Pb}$ dating and trace element analysis. The particles were affixed onto microscope slides using double-sided tape and covered with a PVS ring. After the resin was completely solidified, the sample was removed from the slide and polished to a smooth clean surface. Prior to analysis, the sample surface was carefully cleaned using alcohol, and washed with diluted nitric acid under ultrasound to remove any possible contamination. The detailed analytical conditions, instrument parameters and analyzing procedures are described in the related references $[16,17]$.

\section{Occurrence and morphology of Sr-rich apatite}

Apatite occurred as euhedral crystals with well developed long or short prisms. Prismatic crystals were $1000 \mu \mathrm{m}$ in diameter, but needle-like apatites of only 10-20 $\mu \mathrm{m}$ in diameter also were observed. Some of the apatite crystals exhibited hollow structures with fillings of late-stage minerals (Figure 3(c),(d)). The coexisting minerals included aegirine-augite, clinopyroxene, nephelite, leucite, Ba-rich $\mathrm{K}$-feldspar, ilmenite, aenigmatite, and jonesite. A study of these coexisting minerals will be presented in another paper.

Sr-rich apatite mostly appeared as rims upon earlierforming apatite. However, in the case of hollow-type apatites filled with nephelite or other minerals, Sr-rich apatite also was associated with the internal boundary between apatite and the filling minerals (Figure 3(b),(d)).

Detailed backscattered electron investigations revealed that Sr-rich apatite displayed a straight contact with its host mineral. No replacement between apatite and its host was observed. The surrounding minerals included ilmenite (Figure 3(e)), augite (Figure 3(f)), leucite and nephelite. In Figure 3(f), the augite, including a needle-like Sr-rich apatite, was replaced by nephelite. Furthermore, the Sr-rich apatite re- mained intact, and exhibited an inclusion that cut though the late-stage minerals.

Figure 4 shows the X-ray element scanning and backscattered electron images of an apatite crystal. They clearly reveal the occurrence of Sr-rich apatite on the margin of primary apatite (Figure 4(c)). It is further evident that Sr-rich apatite exhibits irregular, even dentate, contact with primary apatite (Figure 4(c),(f)). The thickness of the Sr-apatite is highly variable, from several to tens of microns. This feature is similar to that of Sr-rich apatites found in the Pilansberg nephelite syenites of South Africa [6].

\section{Chemical composition of Sr-rich apatite}

Electron microprobe results of the two different types of Sr-rich apatite are listed in Table 1. The SrO contents varied significantly from core to rim of single apatite crystals, despite their prismatic or needle-like morphology (e.g. $\mathrm{SrO}$ contents were $0.42 \%-0.8 \%$ in the core for grains 3 and 12 , while their contents were as high as $16.72 \%-26.54 \%$ at the rim). Great variations in $\mathrm{Sr}$ contents also were observed among different apatite crystals. The SrO content was only $0.38 \%-0.63 \%$ in short-prismatic crystals (grains No. 5, 9) and needle-like crystals (grain No. 10). However, grains No. 13 and 14 (short prismatic apatites), and No.7 (needle-like apatite), contained $\mathrm{SrO}$ in the range from $9.06 \%$ to $17.68 \%$. 

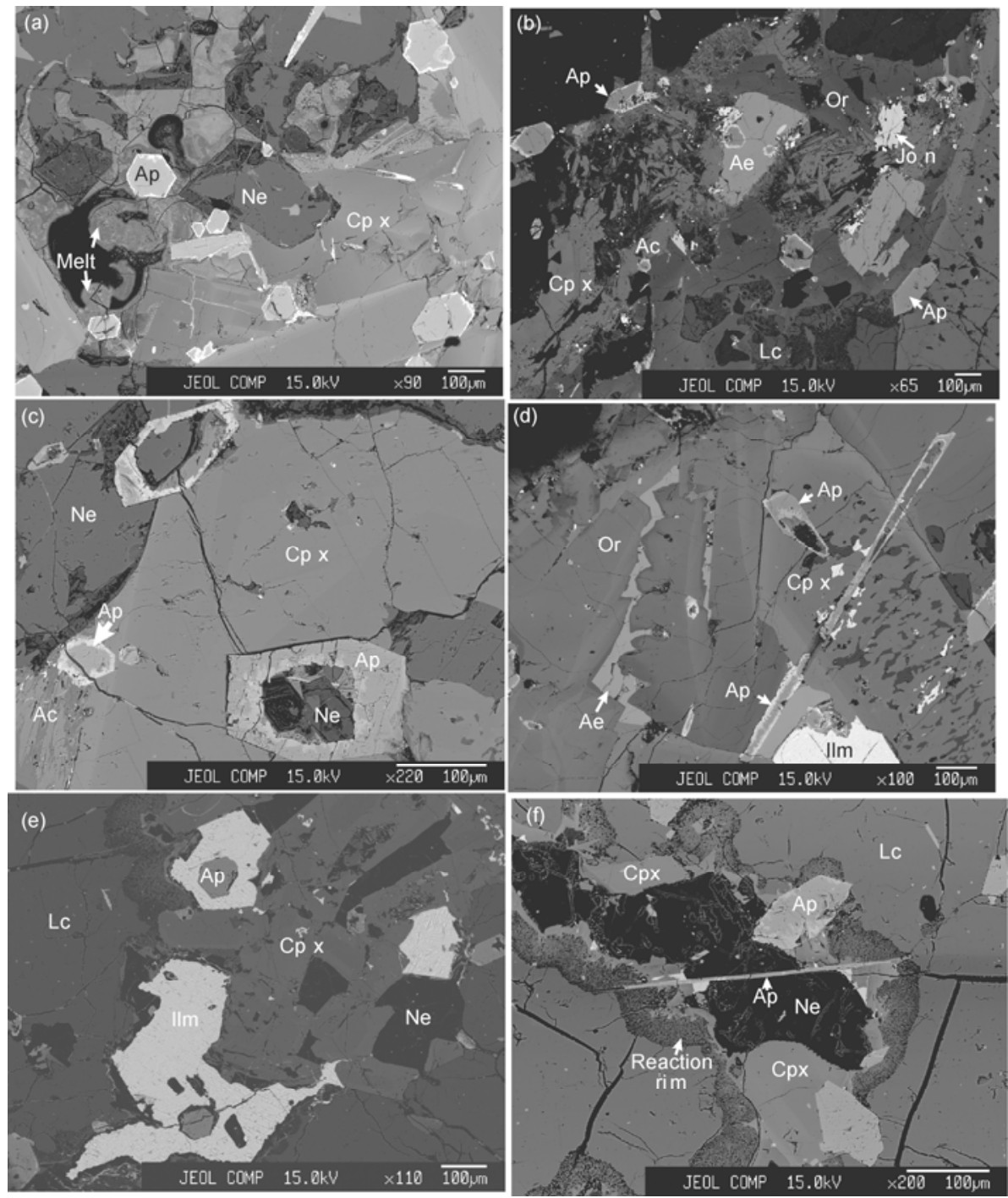

Figure 3 Backscattered electron images of Sr-apatite and coexisting minerals. (a) Idiomorphic zoned crystal of apatite with Sr-rich rim; (b) needle-like Sr-apatite included in aenigmatite; (c) short prisms of apatite with Sr-rich contact with nephelite inclusions; (d) hollow-like Sr-rich apatites included in clinopyroxene; (e) fluorapatite included in ilmenite; (f) Needle-like Sr-apatite included in clinopyroxene which, in turn, is replaced by nephelite with only the shell of clinopyroxene remaining. Ne, nephelite; Lc, leucite; Ae, Aenigmatite; Ap, apatite; Or, orthoclase; Cpx, augite or aegirine; Ilm, ilmenite; Jon, jonesite.

The SrO variations of apatite are likely to be related to its reaction intensity with fluids, which may be indicated by the porosity of the Sr-rich apatites. As shown in Figure 3(e), an apatite crystal covered with the ilmenite revealed no remarkable $\mathrm{Sr}$ enrichment owing to its isolation from Sr-rich fluids. LREE also were present in the apatite to different extents. The Sr-rich rims contained more than 1 wt\% LREE in contrast to their cores, which had about 0.7 $\mathrm{wt} \%$ contents.

As shown in Table 1, the core compositions of apatite were relatively simple, with minor contents of $\mathrm{Sr}$, but were characterized by high values of $\mathrm{F}(>2.5 \mathrm{wt} \%$ ), and $\mathrm{Cl}$ (up to $1.7 \mathrm{wt} \%)$. Therefore, the cores constitute chlorofluorapatite, and may be considered as precursors of the Sr-rich apatite. After fluid metasomatism, primary apatite was transformed into Sr-rich rims with significant chemical changes (Figure 4). Besides increasing $\mathrm{SrO}, \mathrm{Cl}$ decreased from $0.18 \%-1.71 \%$ in primary apatite to $0.04 \%$ or below detection limits for Sr-rich rims (Table 1). Another point to note is the increase in light rare-earth-elements and $\mathrm{Ba}$ in Sr-rich apatite relative to the core. It must also be noted that needle-like apatites were relatively homogeneous in composition, perhaps because crystals forming at this scale completely equilibrated with surrounding formation fluids.

Figure 5 shows the $\mathrm{Sr}-\mathrm{Ca}, \mathrm{LREE}-\mathrm{Ca}, \mathrm{Ba}+\mathrm{Na}-\mathrm{Ca}, \mathrm{Sr}-\mathrm{Cl}$ and $\mathrm{Sr}-\mathrm{OH}$ relationships in the studied apatites. Negative relationships reflect evident substitutions of $\mathrm{Ca}$ by $\mathrm{Sr}$, LREE and $\mathrm{Ba}, \mathrm{Na}$ (Figure 5(a)-(c)). Entering of Sr into the $\mathrm{Ca}$ site was accompanied by $\mathrm{Cl}$ leaching and hydration of the Sr-apatite (Figure 5(d), (e)). 


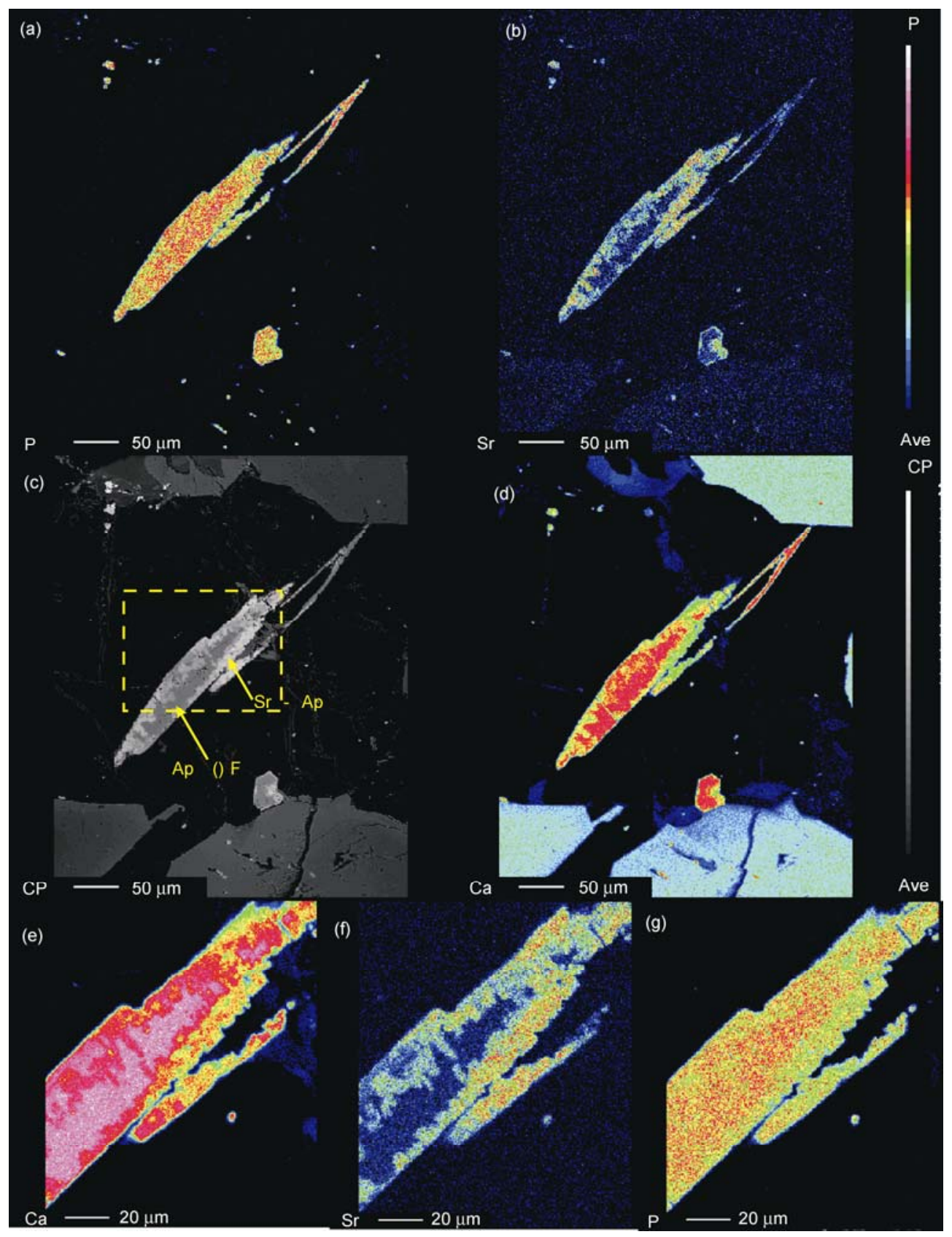

Figure 4 Digital X-ray mapping of Sr-rich apatite. (c) is a false-colored backscattered electron image of Sr-rich apatite. (e)-(g) are X-ray maps of an enlarged area in (c) for elements $\mathrm{P}, \mathrm{Sr}$ and $\mathrm{Ca}$, respectively.

\section{Discussion}

\subsection{Crystal chemistry and isomorphic replacement of Sr-rich apatite}

The general chemical formula for the apatite-group minerals may be represented as $\mathrm{A}_{5}\left(\mathrm{TO}_{4}\right)_{3} \mathrm{X}$. The site $\mathrm{A}$ is occuped by $\mathrm{Ca}$, but can be substitued by other trace elements such as $\mathrm{Sr}$, $\mathrm{Ba}, \mathrm{Pb}, \mathrm{Mn}, \mathrm{LREE}$, and $\mathrm{Na}$. The tetrahedral site $\mathrm{T}$ hosts $\mathrm{P}$ with minor substitution of $\mathrm{Si}$. The $\mathrm{X}$ site includes the additive anions $(\mathrm{F}, \mathrm{Cl}, \mathrm{OH})$. The $\mathrm{A}$ site may be divided into ${ }^{\mathrm{IX}} \mathrm{A}(1)$ and ${ }^{\mathrm{VII}} \mathrm{A}(2)$ sub-sites according to different coordina- tion environments. Therefore, the crystal-chemical formula can be given as ${ }^{\mathrm{IX}} \mathrm{Ca}(1)_{2}{ }^{\mathrm{VII}} \mathrm{Ca}(2)_{3}\left(\mathrm{PO}_{4}\right)_{3}(\mathrm{~F}, \mathrm{Cl}, \mathrm{OH})$.

In most cases, $\mathrm{Sr}$ enters the apatite structure through two different replacement pathways [19,20]:

(i) simple equivalent substitution: ${ }^{\mathrm{VII}} \mathrm{Ca}^{2+} \Leftrightarrow{ }^{\mathrm{VII}} \mathrm{Sr}^{2+}$,

(ii) complex heterovalent substitution: $3^{\mathrm{VII}} \mathrm{Ca}^{2+}+2{ }^{\mathrm{IX}} \mathrm{Ca}^{2+}$ $\Leftrightarrow 3{ }^{\mathrm{VII}} \mathrm{Sr}^{2+}+{ }^{\mathrm{IX}} \mathrm{Na}^{1+}+{ }^{\mathrm{IX}} \mathrm{LREE}^{3+}$ which, in fact, belongs to the belovite-(Ce) solid solution.

Table 1 shows the number of cations of the studied apatite grains, based on the total cations equal to 8 . The negative relationship between $\mathrm{Ca}$ and $\mathrm{Sr}$ for $\mathrm{Sr}$-rich apatite from 

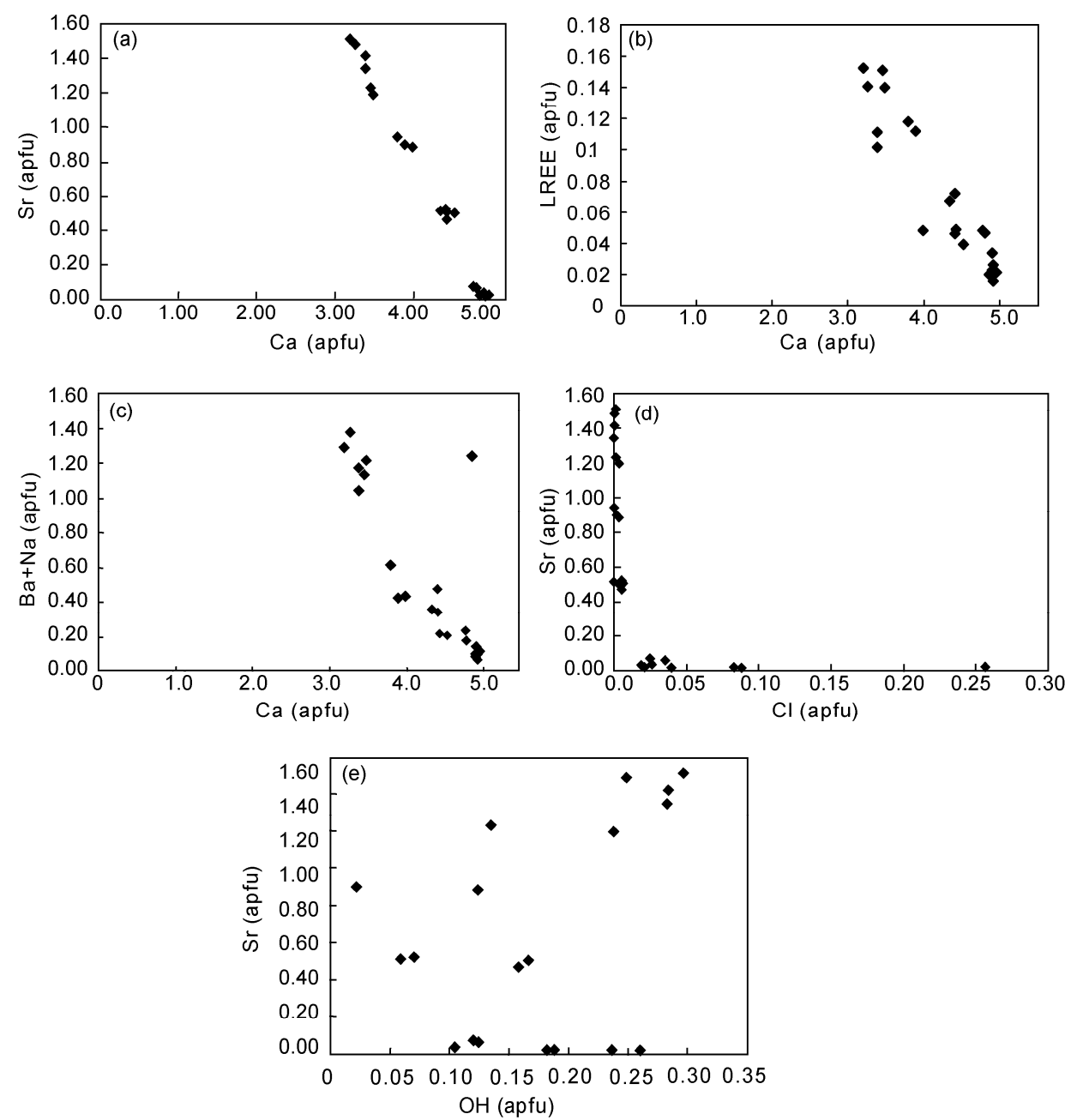

Figure 5 Multi-element relationships in Sr-rich apatite.

Table 1 Electron microprobe data (wt\%) and calculated results of cations (apfu) of apatite from the ijolite xenolith of the Dangzi Mountain

\begin{tabular}{ccccccccccccc}
\hline $\mathrm{Grain}$ & 1 & 2 & & 3 & & & 4 & 5 & & 6 & & 7 \\
\hline Point & 1 & 2 & 3 & 4 & 5 & 6 & 7 & 8 & 9 & 10 & 11 & 12 \\
$\mathrm{wt} \%$ & $\mathrm{r}$ & $\mathrm{r}$ & $\mathrm{r}$ & $\mathrm{r}$ & $\mathrm{c}$ & $\mathrm{r}$ & $\mathrm{r}$ & $\mathrm{c}$ & $\mathrm{F}-\mathrm{ap}$ & F-ap & F-ap & F-ap \\
$\mathrm{P}_{2} \mathrm{O}_{5}$ & 35.74 & 36.98 & 35.09 & 35.78 & 40.08 & 37.63 & 37.02 & 40.74 & 41.13 & 41.18 & 38.37 & 38.44 \\
$\mathrm{SiO}_{2}$ & 0.30 & 0.55 & 0.64 & 0.18 & 0.51 & 0.302 & 1.00 & 0.62 & 0.57 & 0.52 & 0.54 & 0.63 \\
$\mathrm{CaO}$ & 30.63 & 34.16 & 33.04 & 31.48 & 52.55 & 33.51 & 34.73 & 53.34 & 51.58 & 51.33 & 39.42 & 38.43 \\
$\mathrm{FeO}$ & 0.47 & 0.54 & 0.66 & 0.41 & 0.30 & 0.44 & 0.223 & 0.13 & 0.06 & 0.04 & 0.02 & 0.11 \\
$\mathrm{MnO}$ & 0.03 & - & 0.00 & 0.02 & 0.03 & 0.01 & - & 0.05 & 0.01 & 0.01 & 0.00 & 0.01 \\
$\mathrm{MgO}$ & 0.00 & - & - & - & 0.01 & - & 0.01 & 0.09 & 0.02 & 0.04 & 0.01 & 0.01 \\
$\mathrm{SrO}$ & 26.79 & 22.44 & 25.54 & 26.54 & 0.80 & 24.61 & 22.01 & 0.38 & 1.28 & 1.44 & 16.79 & 17.68 \\
$\mathrm{BaO}$ & 0.74 & 0.54 & 0.76 & 0.78 & - & 0.59 & 0.59 & 0.12 & 0.01 & 0.12 & 0.33 & 0.37 \\
$\mathrm{Na} 2 \mathrm{O}$ & 0.54 & 0.51 & 0.48 & 0.58 & 0.06 & 0.45 & 0.55 & 0.06 & 0.10 & 0.12 & 0.17 & 0.27 \\
$\mathrm{~K}_{2} \mathrm{O}$ & 0.02 & 0.02 & 0.03 & 0.02 & 0.02 & 0.01 & 0.08 & 0.01 & 0.04 & 0.05 & 0.05 & 0.17 \\
$\mathrm{La}_{2} \mathrm{O}_{3}$ & 1.37 & 1.48 & 0.95 & 1.42 & 0.31 & 0.94 & 1.36 & 0.18 & 0.40 & 0.40 & 0.84 & 1.02 \\
$\mathrm{Ce} \mathrm{O}_{3}$ & 2.05 & 1.92 & 1.57 & 1.90 & 0.39 & 1.38 & 1.82 & 0.29 & 0.77 & 0.74 & 1.45 & 1.71 \\
$\mathrm{Pr}_{2} \mathrm{O}_{3}$ & 0.20 & 0.30 & 0.17 & 0.14 & 0.03 & 0.28 & 0.22 & - & 0.11 & 0.02 & 0.35 & 0.20 \\
$\mathrm{Nd}_{2} \mathrm{O}_{3}$ & 0.49 & 0.45 & 0.36 & 0.34 & 0.29 & 0.22 & 0.39 & 0.07 & 0.06 & 0.31 & 0.43 & 0.34 \\
$\mathrm{Sm}_{2} \mathrm{O}_{3}$ & 0.00 & 0.02 & - & - & 0.01 & - & 0.13 & 0.17 & 0.10 & - & 0.14 & 0.07 \\
$\mathrm{~F}$ & 2.26 & 2.90 & 2.29 & 2.41 & 3.54 & 2.43 & 2.59 & 2.59 & 3.14 & 3.19 & 3.40 & 3.62 \\
$\mathrm{Cl}$ & 0.00 & 0.01 & - & - & 0.18 & 0.00 & 0.02 & 0.27 & 0.25 & 0.17 & 0.02 & - \\
$\mathrm{F}=\mathrm{O}$ & -0.95 & -1.22 & -0.96 & -1.01 & -1.49 & -1.02 & -1.09 & -1.09 & -1.32 & -1.34 & -1.43 & -1.52 \\
\hline
\end{tabular}




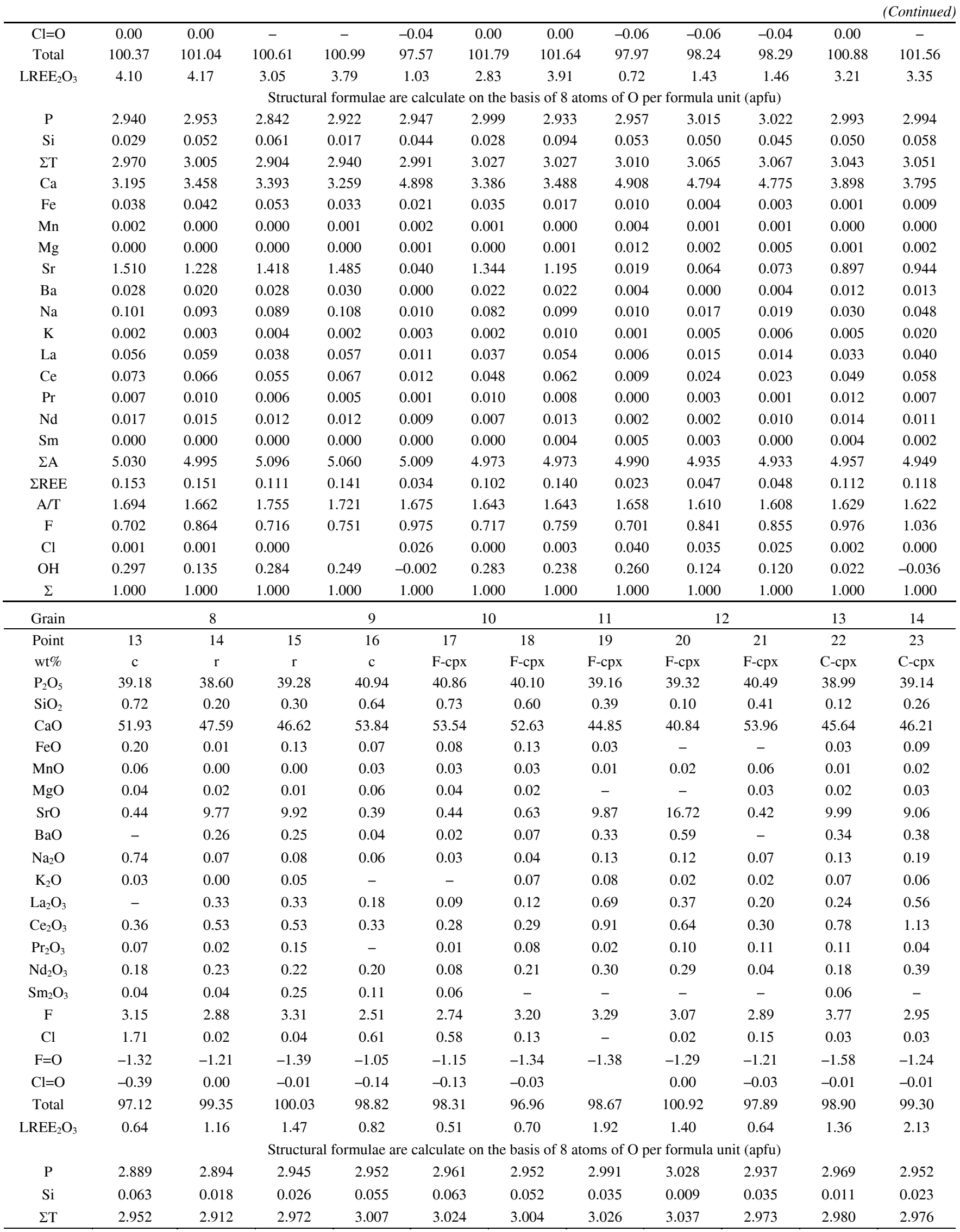




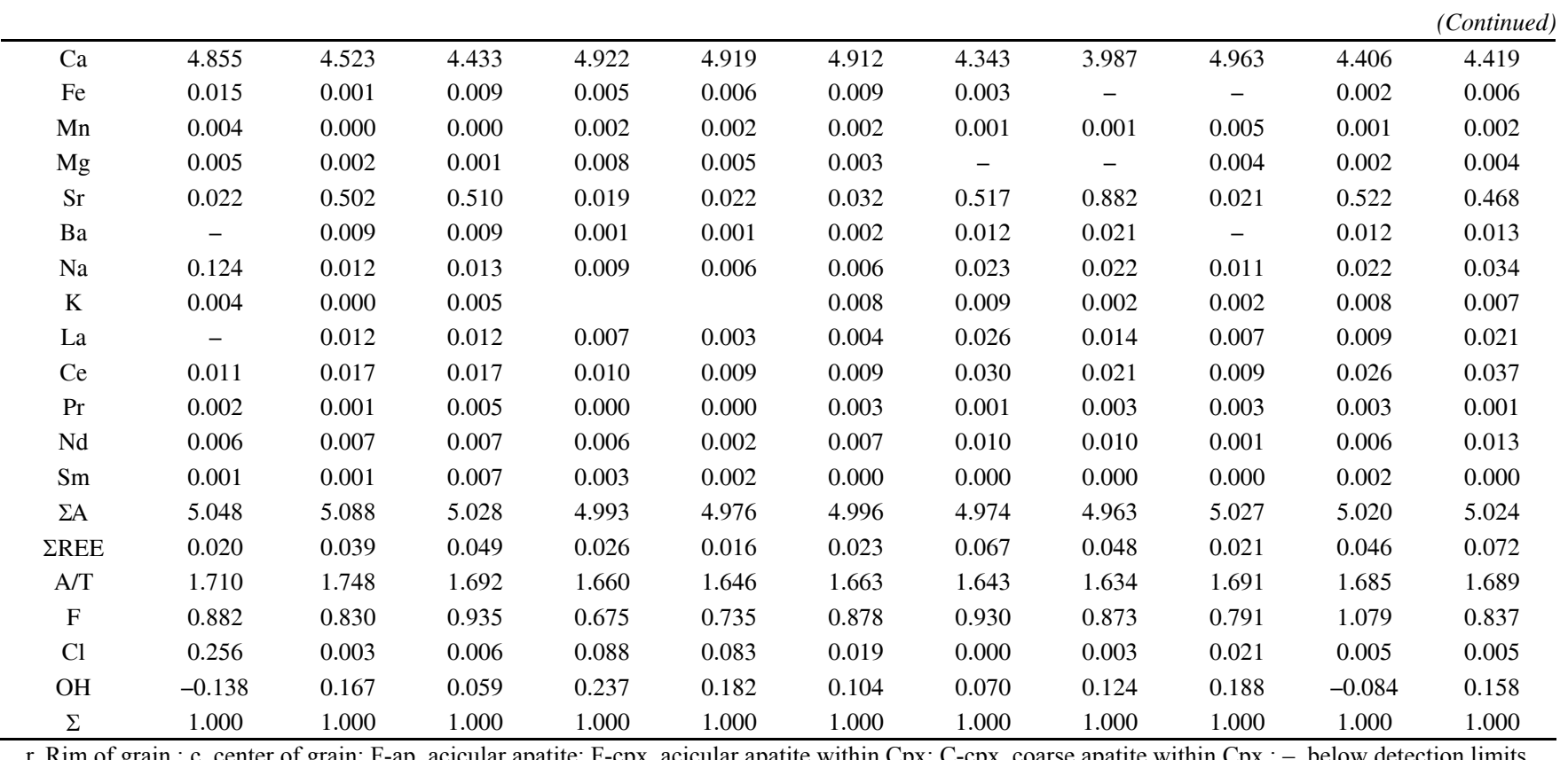

the Dangzi Mountain indicates the presence of the equivalent substitution. However, these apatites also contain minor $\mathrm{LREE}^{3+}$, and $\mathrm{Na}^{+}$to different extents, which have a linear positive relationship. Therefore, coupled heterovalent substitution also may be strongly considered. Taking into account these substitutions, the crystal-chemical formula of Dangzishan apatites can be written as

$$
\begin{array}{r}
\left(\mathrm{Ca}_{3.15-4.963} \mathrm{Sr}_{0.019-1.510} \mathrm{Ba}_{0.00-0.030} \mathrm{Na}_{0.006-0.108} \mathrm{REE}_{0.106-0.153}\right) \\
\left(\mathrm{P}_{2.842-3.028} \mathrm{Si}_{0.009-0.094}\right) \mathrm{O}_{12}\left(\mathrm{~F}_{0.675-1.079}, \mathrm{Cl}_{0.000-0.256}, \mathrm{OH}_{-0.084-0.297}\right)
\end{array}
$$

It is important to note that some of the Sr-rich apatites of Dangzishan displayed a deficiency in T-sites, namely less than 3.0 (e.g. points 1, 3, 4, 5, 13, 14, 15, 21, 22, 23, Table 1). Accordingly, the cations in site A exceeded the ideal value of 5 .

Sr-rich apatite with $\Sigma \mathrm{T}<3$ is common and has been reported worldwide (Table 2) (e.g. in lamproites from West Kimberley, West Australia; Verkhniy Dunkel'dyk Pamir Mountains pseudo-leucite-shonkinite, Tajikistan; Oldoinyo Lengai sodic carbonate, Tanzania).

\subsection{Sr-Nd isotopic composition as tracer of fluid sources}

As discussed above, chloro-fluorapatite initially crystallized from the K-rich ultrabasic alkaline magma (parent magma of the leucitite ijolite), then transitioned to Sr-rich apatite via replacement by $\mathrm{Sr}$-rich fluids. It is of interest to understand the source of these Sr-rich fluids, particularly whether they derived from the same magma as the ijolite. Therefore, additional work on $\mathrm{Sr}-\mathrm{Nd}$ isotopic characteristic of the ijolite bulk-rock, its host-rock and Sr-rich apatite were carried out. In-situ $\mathrm{Sr}$ isotope data on 16 apatite grains and $\mathrm{Nd}$ isotope data on 15 apatite grains were obtained using a Neptune MC-ICP-MS, collected with a $193 \mathrm{~nm}$ laser. The $\mathrm{Sr}-\mathrm{Nd}$ isotopic compositions of an ijolite xenolith and its host rock also were obtained using the VG354 Solid Mass Spectrometer at the Institute of Geology and Geophysics, Chinese Academy of Sciences. All results are shown in Table 3 and Figure 6.

$\mathrm{Sr}-\mathrm{Nd}$ isotopic compositions of Sr-rich apatites vary little $\left({ }^{87} \mathrm{Sr} /{ }^{86} \mathrm{Sr}=0.70488\right.$ to 0.70506 , and ${ }^{143} \mathrm{Nd} /{ }^{144} \mathrm{Nd}=0.51242$ to 0.51251 ). In Figure 6 , the data points are concentrated in the upper left corner of the enriched-mantle area. $\mathrm{Sr}-\mathrm{Nd}$ isotopic compositions of the leucitite-ijolite xenolith and its host rock were similar to the ${ }^{87} \mathrm{Sr} /{ }^{86} \mathrm{Sr}$ ratios of 0.70543 and 0.70559 , respectively, and ${ }^{143} \mathrm{Nd} /{ }^{144} \mathrm{Nd}$ ratios of 0.511821 and 0.511761 , respectively, both of which clearly were separated from those of the Sr-rich apatites of Figure 6. Although projected similarly in the enriched-mantle area, the

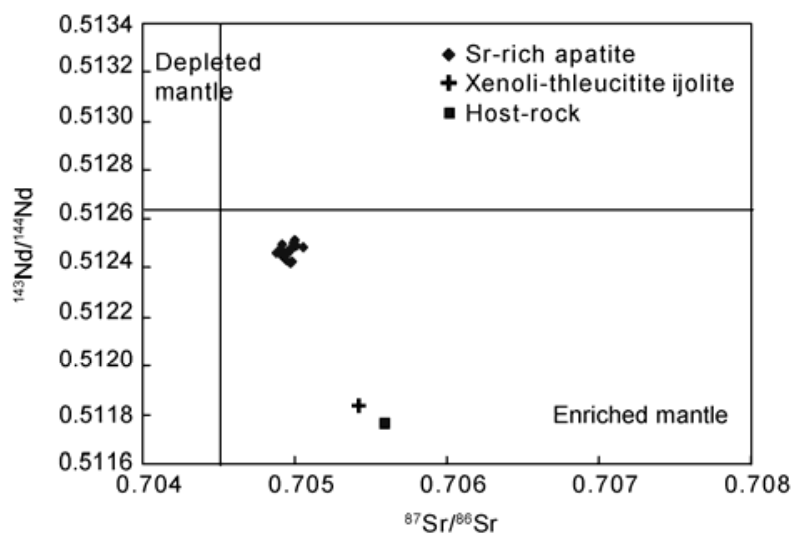

Figure $6 \mathrm{Sr}-\mathrm{Nd}$ isotopic composition for $\mathrm{Sr}$-rich apatite grains, leucitite ijolite xenolith and its host rock. 
Table 2 Summary of Sr contents of Sr-rich apatite in the Dangzi Mountain and other areas throughout the world

\begin{tabular}{|c|c|c|c|c|c|}
\hline \multirow[t]{2}{*}{ Rock type } & \multicolumn{2}{|c|}{ SrO content } & \multirow[t]{2}{*}{ Locality } & \multirow[t]{2}{*}{ Comments } & \multirow[t]{2}{*}{ References } \\
\hline & $\mathrm{wt} \% \mathrm{SrO}$ & apfu & & & \\
\hline \multicolumn{6}{|l|}{ Igneous rocks } \\
\hline Leucitite-ijolite & $0.4-26.8$ & $0.02-1.51$ & Dangzimountain, China & Fluorapatite, deficiency in T-site & this work \\
\hline Kimberlite & 40.2 & 2.32 & Lac de Gras, NWT Canada & $\mathrm{CO}_{2}$-bearing apatite, high $\mathrm{Si}$ and $\mathrm{Ba}$ & [2] \\
\hline Lamproite & 5.8 & 0.29 & West Kimberley, Australia & Very high Ba, deficiency in T-site & [3] \\
\hline Orangeite & 21.7 & 1.18 & Besterskraal, South Africa & Moderate REE, Si and Ba & [21] \\
\hline Lamprophyre & 14.0 & 0.73 & Murun, Yakutia, Russia & Fluorapatite, elevated REE and $\mathrm{Si}$ & [2] \\
\hline Fergusite & 8.2 & 0.43 & $\begin{array}{c}\text { Verkhniy Dunkel'dyk, Pamir Mts., } \\
\text { Tajikistan }\end{array}$ & High deficiency in T-site, moderate $\mathrm{Si}$ and $\mathrm{Ba}$ & [22] \\
\hline Nephelite & 24.6 & 1.38 & Djebel Targou, Morocco & Fluorapatite, high Si and moderate REE & [23] \\
\hline Foidolite & 12.0 & 0.63 & Lovozero, Russia & Fluorapatite, moderate REE & [24] \\
\hline Phonolite & 29.8 & 1.72 & Mt. Kamasurt, Lovozero, Russia & Fluorapatite, high Si and REE & [2] \\
\hline Malignite & 8.7 & 0.44 & Gordon Butte, Montana, USA & Fluorapatite & [2] \\
\hline Foyaite & 20.2 & 1.13 & Mt. Selsurt, Lovozero, Russia & High Na and REE, overgrown by belovite-(Ce) & [2] \\
\hline $\begin{array}{l}\text { Ne-syenites } \\
\text { Sodic }\end{array}$ & 37.5 & 2.33 & $\begin{array}{l}\text { Russia } \\
\text { Mt. Alluaiv, Lovozero }\end{array}$ & $\begin{array}{l}\text { Hydroxylapatite, moderate REE and Na } \\
\text { Fluorapatite, negligilbe Na, Si and REE }\end{array}$ & [2] \\
\hline Potassic & 39.6 & 2.49 & Murun, Yakutia & & \\
\hline Alkaline syenite & 19.2 & 1.03 & Gordon butte, Montana, USA & Low $\mathrm{Na}, \mathrm{REE}$ and $\mathrm{Si}$ & [2] \\
\hline \multicolumn{6}{|l|}{ Metasomatic rocks } \\
\hline Fenite & 5.6 & 0.29 & Mt. Bisson, BC, Canada & Fluorapatite, moderate REE & [25] \\
\hline Albite-aegirine & 26.4 & 1.63 & Mt. Flora, Lovozero, Russia & Fluorapatite(?), very high $\mathrm{Na}$ and REE & [2] \\
\hline \multicolumn{6}{|l|}{ Carbonatites } \\
\hline Calcite & 5.0 & 0.26 & Gatineau, Quebec, Canada & Fluorapatite, moderate $\mathrm{Na}, \mathrm{REE}$ and $\mathrm{Si}$ & [26] \\
\hline Dolomite & 13.3 & 0.70 & Lesnaya Varaka, Russia & Fluorapatite, negligible $\mathrm{Na}$, and $\mathrm{REE}$ & [2] \\
\hline Ankerite & 8.2 & 0.41 & Chipman lake, Ontario, Canada & & [5] \\
\hline Natrocarbonatite & 3.7 & 0.18 & Oldoinyo Lengai, Tanzania & $\begin{array}{l}\text { Fluorapatite, strong deficiency in T-site, } \\
\text { moderate } \mathrm{Si}\end{array}$ & [4] \\
\hline Barytocalcite & 6.7 & 0.33 & Murun, Yakutia, Russia & Hydroxylapatite: Significant F & [2] \\
\hline
\end{tabular}

Table 3 Sr-Nd isotopic compositions of Sr-rich apatite, leucite ijolite xenolith and the host rock

\begin{tabular}{ccc||ccc}
\hline Sample & ${ }^{87} \mathrm{Sr}{ }^{86} \mathrm{Sr}$ & 2 & Sample & ${ }^{143} \mathrm{Nd} /{ }^{144} \mathrm{Nd}$ & 2 \\
\hline AP Sr 01 & 0.70492 & 0.00005 & AP 01 & 0.512465 & 0.000039 \\
AP Sr 02 & 0.70492 & 0.00006 & AP 02 & 0.512495 & 0.000032 \\
AP Sr 03 & 0.70499 & 0.00005 & AP 03 & 0.512499 & 0.000030 \\
AP Sr 04 & 0.70500 & 0.00006 & AP 04 05 & 0.512511 & 0.000027 \\
AP Sr 05 & 0.70496 & 0.00003 & AP 05 06 & 0.512471 & 0.000036 \\
AP Sr 06 & 0.70493 & 0.00005 & AP 07 & 0.512443 & 0.000040 \\
AP Sr 07 & 0.70494 & 0.00006 & AP 08 & 0.512432 & 0.000038 \\
AP Sr 08 & 0.70498 & 0.00006 & AP 09 & 0.512424 & 0.000036 \\
AP Sr 09 & 0.70506 & 0.00007 & AP 10 & 0.512482 & 0.000025 \\
AP Sr 10 & 0.70495 & 0.00007 & AP 11 & 0.512457 & 0.000040 \\
AP Sr 11 & 0.70501 & 0.00006 & AP 12 & 0.512487 & 0.000031 \\
AP Sr 12 & 0.70488 & 0.00005 & AP 13 & 0.512460 & 0.000037 \\
AP Sr 13 & 0.70497 & 0.00006 & AP 14 & 0.512421 & 0.000043 \\
AP Sr 14 & 0.70489 & 0.00006 & AP 15 & 0.512465 & 0.000033 \\
AP Sr 15 & 0.70497 & 0.00004 & & 0.512469 & 0.000030 \\
AP Sr 16 & 0.70493 & 0.00007 & & & \\
DZ-C & 0.70543 & & & 0.511821 & \\
DZ-14 ${ }^{\text {b) }}$ & 0.70559 & & & 0.511761 \\
\hline
\end{tabular}

a) and b) DZ-C and DZ-14 are the samples of leucite ijolite xenolith and its host rock, respectively. 
apatite and the xenolith have distinctive Sr-Nd compositions, therefore suggesting different origins. In fact, the $\mathrm{Sr}-\mathrm{Nd}$ isotopic composition of the $\mathrm{Sr}$-rich apatites may have originated from both the Sr-rich fluids and the magma which formed the leucitite ijolite. Because the source area of the ijolite-forming magma was enriched in mantle components, the Sr-rich fluids are believed to have been closer in composition to the depleted mantle. Leucitite-ijolite xenoliths and the host rock should be products from the same source. The slight depletion of the former is probably due to Sr-rich fluid replacement.

\subsection{Sr content in apatite as a basicity indicator of the melt}

Liferovich et al. [6] studied the Pilansberg nephelite syenite (South Africa), which was shown to have experienced post-magmatic subsolidus equilibration derived from the same-sourced $\mathrm{Cl}$ and $\mathrm{Na}$ fluids, as indicated by the alteration in primary aluminosilicates (rinkite, eudialite) and Frich apatite. Secondary mineral assemblages better reflected the $\mathrm{Na} / \mathrm{Cl}$ ratio in the Na-rich and $\mathrm{Cl}$-rich fluids, as well as the $\mathrm{pH}$ value of the post-magma interval. Because of extensive interactions between the fluids and the original and secondary minerals, the composition of the fluids exhibited a continuously changing characteristic, and the basicity of whole system fluctuated with it. Hence, the apatites were very sensitive to the late magma period fluids, and cation variation in the apatites constitutes an indicator of fluid evolution in the post-magma interval. When basicity increased, more $\mathrm{Ca}$ was replaced by $\mathrm{Sr}$ in apatites. However, when basicity decreased, $\mathrm{Na}$, LREE and $\mathrm{Sr}$ were removed from the apatite's lattice and resulted in a decrease of these cations. It is evident that the more $\mathrm{Na}, \mathrm{K}, \mathrm{Sr}, \mathrm{Ba}$ and other alkali cations present in the fluids, the higher the basicity in the system. Thus, the more chemically active the system, the more probable and intensive the reactions with the mineral will be. Consequently, the very active cations in the fluid, such as $\mathrm{Na}, \mathrm{K}, \mathrm{Sr}$ and $\mathrm{Ba}$, can easily replace relatively inert cations in the mineral.

Figures 2 and 4 show that regardless of whether the Sr-rich apatite was short prismatic or needle-like, the closer the apatite was to the margin, the higher the Sr content. The highest $\mathrm{Sr}$ apfu was 1.51, which indicates that basicity of the system gradually increased during the formation of the Sr-rich apatites. The Sr-rich apatites in the Pilansberg nephelite syenite possessed a $\mathrm{Sr}$ apfu of $4.24(\mathrm{SrO}=62$ wt\%) [6]. As a comparison, the total $\mathrm{Sr}$ cation number in Lovozero and Murun Sr-rich apatites from the Russian Kola peninsula can reach 4.66 apfu [2,6]. The basicities of these syenites are much higher than that in the Dangzi Mountain.

\subsection{Significance of Sr-rich apatites to regional litho- spheric evolution}

The occurrence of Sr-rich apatite in leucitite-ijolite xeno- liths allows a better understanding of regional tectonic setting. Previous petrographic and geochemical studies by our group on the Dangzishan Neogene murambite, containing leucitite-ijolite xenoliths and another harzburgite xenoliths, suggest that the lithospheric mantle represented by the harzburgite evolved to the EMI mantle as a consequence of alteration by fluid containing incompatible elements from the asthenosphere. The K-rich volcanic rock and its leucitite-ijolite xenoliths were generated from partially melted magma from different parts of an enriched mantle [15]. The Sr-rich apatites discussed above represent direct evidence of replacement by incompatible element-enriched fluids. As shown in Table 2, Sr-rich apatites from the Dangzishan ijolite xenoliths are comparable with those found in alkaline rocks in the Kola Peninsula and worldwide, which are related to typical enriched-mantle source areas.

The above-mentioned magma source and upwelling of associated fluids are closely related to tectonic setting. We have suggested that the Xiaogulihe-Keluo-WudalianchiErkeshan Cenozoic K-rich ultrabasic volcanic belt is a developing and evolving continental rift, which extends to approximately $400 \mathrm{~km}$ long and $50 \mathrm{~km}$ wide. This rift belt controlled fluvial landscapes in the Quaternary Period; preserved many large-scale volcanic events recorded in human history; and still experiences earthquakes, geothermal activity, degassing and other abnormal phenomena today [15]. Based on this information, we also conducted a more detailed investigation on the northernmost Xiaogulihe basic and ultrabasic ultrapotassic volcanic rocks, and suggest that its geochemical characteristics can be compared with the famous leucite in Leucite hills (USA), kamafugite in the Apennines (Italy), and olivine leucitite from the west branch of the East African Rift [27]. Further comparisons with these world-famous continental-rift volcanic rocks will help deepen our understanding of the formation environment of Sr-rich apatites.

The analyses of the formation mechanism and $\mathrm{Sr}-\mathrm{Nd}$ isotopic compositions of the Sr-rich apatites from the Dangzishan volcanic rocks presented herein reveal frequent and multi-source mantle fluid activities in this region; implying that the EMI end-member was derived from mantle fluids of a different source area. Therefore, the discovery of Sr-rich apatite provides direct evidence for the formation of a regional EMI mantle.

\section{Conclusions}

Sr-rich apatite found in the Dangzishan leucitite-ijolite xenoliths originated from chloro-fluorapatite formed from magma crystallization, which suffered an isomorphic replacement along crystal edges by Sr-rich fluids from relatively depleted-mantle source areas.

The SrO contents of these Sr-rich apatites depended on the intensity of the replacement, mostly related to the poros- 
ity of the primary apatite on the one hand, and to the activities of the fluids on the other.

The $\mathrm{SrO}$ variations in apatite reflect the changing basicity in the melt. Taking into account that the highest $\mathrm{SrO}$ content is always found on the rims of apatite grains, it is believed that the basicity of the melt gradually increased.

Both the Sr-rich apatite-bearing leucitite-ijolite xenoliths and their host rocks were formed in an active continental rift setting. Their elemental and isotopic characteristics imply that mantle-fluid activities in this region were frequent and multi-sourced. Furthermore, formation of the EMI-type mantle end-member is suggested to have been composed of mantle fluids from different source areas. Therefore, the discovery of Sr-rich apatites provides direct evidence for the presence of an enriched metasomatic mantle in this region.

We would like to give our sincere thanks to two reviewers for their suggestions. We also would like to express our appreciation to Dr. Chen Lihui for his help with Sr-Nd isotope analyses. This work was supported by the National Natural Science Foundation of China (40672039, 41372103 and 40221301).

1 Chakhmouradian A R, Ekater P R , Mitchell R H. Primary, agpaitic and deuteric stages in the evolution of accessory Sr, REE, Ba and $\mathrm{Nb}$-mineralization in nepheline-syenite pegmatites at Pegmatite Peak, bearpaw Mts, Montana. Mineral Petrol, 1999, 67: 85-110

2 Chakhmouradian A R, Ekater P R, Mitchell R H. Strontium-Apatite: New occurrences, and extent of Sr-for-Ca Substitution-group minerals. Canad Mineral, 2002, 40: 121-136

3 Edgar A D. Barium- and strontium-enriched apatites in lamproites from West Kimberley, West Australia. Am Mineral, 1989, 74: 889_ 895

4 Dawson J B. Asupposed soviet from oldoinyo Lengai, Tanzania: result of extreme alteration of alkali carbonatite lava. Mineral Mag, 1993, 57: 93-101

5 Platt R G, Woolley A R. The carbonatites and fenites of Chipman Lake, Ontario. Canad Mineral, 1990, 28: 241-250

6 Liferovich R P, Mitchell R H. Apatite-group minerals from nepheline syenite, Pilansberg alkaline complex, South Africa. Mineral Mag, 2006, 70: 463-484

7 Zhang P S, Tao K J. Bayun Obo Mineralogy (in Chinese). Beijing: Science Press, 1986. 125-131

8 Wang X J, Zou T R, Xu J G, et al. Study of Pegmatite Minerals of Altay Region (in Chinese). Beijing: Science Press, 1981. 1-140

9 Zhang Y B, Xu C Y, Xiao M Y, et al. Study on Fe, Cu mineralization generated in subaqueous carbonatitic volcano-hydrothermal activity and their large insidious ore deposit prospecting in the northward of
Lishi, Yimen, Central Yunnan (in Chinese). Acta Petrol Sin, 2005, 21: $1395-1408$

10 Du L T, Rong J S. Geochemistry of Alkalis (Na K) in Mantle Fluids. Geochemistry of Mantle Fluids and Asthenosphere (Asthenoliths), Chapter 5 (in Chinese). Bejing: Geological Publishing House, 1996. 154-230

11 Shao J A, Wang Z H. Phosphatic melt and apatite of the limburgite in Harqin (in Chinese). Acta Petrol Sin, 2000, 16: 449-453

12 Liu M H. Discovery phlogopite spinel iherzolite inclusion from alkaline basalt in the Keluo area (in Chinese). Geol Geochem, 1986, 7: 69-70

13 Qiu J X, Liao Q A, Liu M H, et al. The K-rich Volcanoic Rochs in Wudalianchi-Keluo-Erkeshan (in Chinese). Wuhan: China University of Geosciences Press, 1991. 95-99, 168-174

14 Mu Z G, Liu C, Huang B L, et al. K-Ar ages and geochemistry of the Late-Cenozoic volcanic rocks in Keluo, Heilongiiang Province (in Chinese). Acta Sci Nat Univ Peking, 1992, 28: 733-744

15 Shao J A, Zhang W L, Zhang C. Mantle enrichment of Wudalianchi volcanic rock belt (in Chinese). Acta Petrol Sin, 2008, 24: 2485-2494

16 Yang Y H, Sun J F, Xie L W, et al. In-situ Nd isotopic measurement of natural geological materials by LA-MC-ICP-MS. Chinese Sci Bull, 2008, 53: 568-576

17 Yang Y H, Wu F Y, Xie L W, et al. In-situ Sr isotopic measurement of natural geological samples by LA-MC-ICP-MS (in Chinese). Acta Petrol Sin, 2009, 25: 3431-3441

18 Nadezhina T N, Pushcharovskii D Yu, Khomyakov A P. Refinement of crystal structure of belovite (in Russian). Mineral Zhurnal, 1987, 9: $45-48$

19 Pushcharovskii D Yu, Nadezhina T N, Khomyakov A P. Crystal structure of strontium-apatite from Khibiny. Sov Phys Crystallogr, 1987, 32: 524-526

20 Rakovan J F, Hughes J M. Strontium in the apatite structure: Strontian fluorapatite and belovite-(Ce). Can Mineral , 2000, 38: 839-845

21 Mitchell R H. Kimberlite, Orangeites, and Related Rock. New York: Plenum Press, 1995. 1-410

22 Solovova I P, Girnis A V, Guzhova A V. Carbonatite melts in East Pamir alkali basaltoids. Geochem Int, 1993, 30: 74-85

23 Velde D, Rachdi H E N. Influence of Sr on an estabished petrological incompatibility: The association melilite $+\mathrm{K}$-feldspar in a nepheline from Djebel Targou, central Morocco. J Petrol, 1988, 29: 585-597

24 Bussen I V, Sakharov A S. Petrology of the Lovozero Alkaline Massif (in Russian). Moscow: Nauka Press, 1972

25 Halleran A D, Russell J K. REE-bearing alkaline pegmatites and associated light REE-enriched fenites at Mount Bisson, British Columbia. Economical Geol, 1996, 91: 451-459

26 Hogarth D D, Hartree R, Loop J, et al. Rare-earth element minerals in four carbonatites near Gatineau, Quebec. Am mineral, 1985, 70: 1135 $-1142$

27 Shao J A, Zhang W L, Zhou X H, et al. Discovery of Xiaogulihe perpotasaic basic and ultrabasic volcanic rock in the north-west Heilongjiang provice, China (in Chinese). Acta Petrol Sin, 2009, 25: 2642-2650

Open Access This article is distributed under the terms of the Creative Commons Attribution License which permits any use, distribution, and reproduction in any medium, provided the original author(s) and source are credited. 